\title{
Strategic Communication Requires Strategic Thinking
}

https://doi.org/10.21814/uminho.ed.46.2

\section{Peggy Simcic Bronn}

Department of Communication and Culture, Norwegian Business School, Oslo, Norway https://orcid.org/0000-0003-2541-8350 



\begin{abstract}
Using a definition of strategic communication that focuses on communication that is critical for the "survival and sustained success of an entity" (Zerfass, Verčič, et al., 2018, p. 487), this chapter argues that to be successful, strategic communication needs communication leaders who are strategic thinkers and who take a systems approach. The chapter begins with a brief overview of strategic communication. This is followed by a discussion of what is meant by strategy and where strategic communication fits in strategic planning. The chapter then takes up the idea that to be part of strategic decision making, communication executives need to exhibit competencies in strategic thinking. Much of the work in this chapter is based on previous research by the author, who found that leaders who view their communication directors as having a strategic orientation are more likely to value them and the contribution of the communication function to their organization's success. But not only that, communication executives demonstrating a strategic orientation are more likely to be invited to strategic meetings, and they would be invited early in the process.
\end{abstract}

\title{
Keywords
}

strategic communication, strategic thinking, strategy, systems thinking, proactive

\section{Strategic Communication}

There are many definitions of strategic communication. However, many researchers credit a seminal definition of strategic communication to Hallahan et al. (2007) in the first edition of the International Journal of Strategic Communication in 2007. According to these authors, strategic communication is "the purposeful use of communication by an organization to fulfill its mission" (Hallahan et al., 2007, p. 3). They differentiate strategic communication from integrated communication, which attempts to coordinate communication activities such as public relations and marketing communication. For them, strategic communication "is how an organization communicates across organizational endeavors" and "how an organization functions as a social actor to advance its mission" (Hallahan et al., 2007, p. 7).

Zerfass, Verčič, et al. (2018) build on this definition to define strategic communication as encompassing: 
all communication that issubstantial for the survival and sustained success of an entity. Specifically, (...) [it] is the purposeful use of communication by an organization or other entity to engage in conversations of strategic significance to its goals. (p. 493)

Key to this definition is the word "substantial", as in issues facing an organization that are substantial or significant for an organization/entity's "development, growth, identity or survival" (Zerfass, Verčič, et al., 2018, p. 493). According to the authors, this separates strategic communication from communication that may have a purpose but where the purpose is operational rather than strategic.

Another view of strategic communication is offered by Botan (2018), who views it is as "the use of information flowing into the organization (research) to plan and carry out a communication campaign addressing the relationship between an organization and its publics" (p. 29). For Botan (2018), strategic communication is research based, and publics centered rather than organization or message centered. He differentiates between those who plan and those who implement by saying the planner is being strategic while the implementer is just practicing tactical communication.

Argenti et al. (2015) define strategic communication as "communication aligned with the company's overall strategy, to enhance its strategic positioning" (p. 61). For them, strategic communication is an essential influence on corporate strategy.

This chapter focuses on communication as supporting the survival and sustained success of the organization. To do this, it is necessary for communication executives to contribute to strategy and strategic decisions at the highest level of the organization. This demands distinguishing between an operational purpose and a strategic one, a strategic plan and a tactical one.

\section{Strategy and Strategic Decisions}

The idea of strategy and being strategic is widely discussed in the public relations literature (for a discussion on strategy and the communication field see Frandsen and Johansen, 2017) but is particularly significant when discussing strategic communication.

Strategy is a field of study and practice that is concerned with the overall performance of a system, usually in terms of human activity systems. 
Strategy implies a high-level perspective, a broader scope, and greater responsibility that contrasts with the tactical or operational levels of the firm. Strategy is about planning based on long-term goals and objectives, while at the same time acting and allocating resources to achieve goals and objectives. Strategies determine courses of action and should address how to gain and sustain advantage over competitors, all in a dynamic and changing business environment (Dhir et al., 2018).

A very simplistic picture of planning and strategy comprises three levels: corporate planning and strategy, business planning and strategy, and functional planning and strategy (Chakravarthy \& Lorange, 1991). Corporate planning is at the top level and is where corporate objectives are established that lead to forming the corporate strategy. The organization's objectives and goals are determined here along with decisions on acquiring and allocating resources. This is where the overall direction of the organization is set, including its vision and mission. Botan (2018) refers to plans made at this level as the grand strategy, or policy-level decisions made about goals, alignments, ethics, relationships, and other issues in the organization's environment.

Business planning leads to formulation of business strategies, that is, the scope of what different individual units or divisions will do to satisfy overall organizational strategy. Strategies at this level are subordinate to the grand strategy. Involvement at this level is by lower level managers. These lower level strategies become operational and culminate at the functional level where managers are most concerned with the specific details of implementing strategies decided at the upper levels. Involvement is by even lower level managers and their teams who have responsibility for functions such as marketing, sales, engineering, and so on.

Strategic decisions are those decisions that determine an organization's overall direction and viability. Decisions of this kind have a long-term perspective. In contrast, operational decisions tend to focus on the short term and are anchored in the strategic plans of the organization. Operational decisions result in specific actions that are narrower in scope and that organizations must carry out to implement higher level strategies. For example, a marketing strategy involves decision making on issues of product mix, promotional and advertising activities, budgeting, and timing. An operational decision might, for instance, relate to price setting in a particular geographic region. 
This overly simplistic view ignores many aspects of strategy and planning; however, it illustrates that corporate planning provides the strategic umbrella under which lower level strategies are drafted or operationalized. People involved at this level are normally from what is called the top management team or dominant coalition, including the chief executive officer and others who perhaps hold titles such as executive director or senior vice president. Being involved in strategic planning requires being part of the dominant coalition or top management team. Therefore, if strategic communication professionals want to have an influence on strategic decisions and engage in conversations of strategic significance, they must participate in strategic decision making. This is as true for communication executives as for any other executive. As noted by Broom and Dozier (1986), it is important for public relations leaders to play an integral role in strategic decision making so that they can effectively help the organization achieve its mission, goals, and objectives.

\section{History of Communication Executives Involvement in Strategic Planning}

The degree of involvement by communication executives in strategic planning has been the subject of study by public relations research scholars for many years, and an ongoing concern of practitioners. Examples of research include: L. A. Grunig (1992) - public relations practitioners are seldom included in the dominant coalition -; White and Dozier (1992) - communication managers are rarely formally empowered as decision-makers at the strategic level where they would encounter the dominant coalition -; and J. Grunig (2006) - reasons for this include lack of broad business expertise, passivity, naiveté about organizational politics, and inadequate education, experience or organizational status.

Several antecedents have been identified within the public relations literature as necessary for participating in strategic decision-making. These include managers' previous education, their perceived position in the organization, and the dominant role enacted by the public relations manager. It is this last antecedent that has received the most attention however as a determinant of whether public relations practitioners participate in strategic decision making. Two primary roles have been identified: the technician role and the managerial role. These two roles represent the main role dichotomy of public relations practitioners within organizations and provide the basis for several propositions dealing with role enactment. 
According to Dozier (1992), those who enact primarily the manager role are more likely to be involved in management decision making. While the technician is seen as someone who produces, for example, brochures, pamphlets (the various task-related or operational aspects of public relations); the managerial role, as described by Dozier, is measured by asking respondents if they (a) take responsibility, (b) are viewed as an expert, (c) observe that they are held accountable, (d) make policy decisions, (e) operate as a catalyst in management decision making, (f) recognize the need for planning, and $(\mathrm{g})$ keep management informed.

These claims are still being tested. For example, Wilson (2016) found that top management team members' "perceptions of the manager role potential of the Public Relations department was the strongest predictor of their perceptions that the department participates in organizational decision making" (p. 226). Recent work by Cardwell et al. (2017) found that internal relationship management is a "prerequisite to corporate Public Relations practitioners' success in developing mutually beneficial relationships with key publics" (p. 152). The authors maintain that their findings have implications for the discussion of the technician versus strategic manager role of public relations and the advancement of the field to a professional status.

While it seems that enacting the managerial role is key for public relations practitioners to be accepted by their executive peers, Cardwell et al. (2017) note that communication practitioners still struggle with their status in organizations, and there appears to be little research providing guidance on how to improve it. However, in 2001, Brønn (2001) raised the question if focusing on role enactment is the right metric for measuring a communication practitioner's acceptance by the top management team. Enacting the managerial role, by some accounts, is after all nothing more than performing high-level technical activities. A new measurement of managerial competency is necessary, strategic thinking.

\section{New Antecedent - Strategic Thinking}

Katzenbach (1996) asserts that managers know how to do things - they can create budgets, enforce policies, and carry out procedures, and today, being a manager is not as important as being a "leader". Hinterhuber and Popp (1993) differentiate between strategic leaders and operational leaders. Operational leaders have skills that enable them to manage resources. Strategic leaders, on the other hand, are skilled in "selecting future markets 
to enter and achieving growth for the organization" (Zabriskie \& Huellmantel, 1991, pp. 25-26). There is a clear dividing line between managers and strategists, those who are successful at, among other things, visioning, empowering, and embracing an entrepreneurial approach to business.

According to Mintzberg (1989) the only necessary competency for helping with the planning process is sharp minds in touch with the situation. He proposes that the best thing planners can do is to stimulate others to think strategically, and that the real art of planning has to do with the ability to detect what he calls discontinuities.

Schilit (1993) found that the most often-mentioned method of upward influence between middle-level managers and their superiors in strategic decisions was the ability to logically present ideas through rational or persuasive argument. Finally, Vaghefi and Huellmantel (1998) found that at the leadership level of senior manager, defined as directors, vice presidents, executive vice presidents, among others, $70 \%$ of the skills needed were strategic-conceptual and entrepreneurial, which they defined as strategic thinking, scenario planning, and issues management. Chakravarthy and Lorange (1991) list nurturing strategic thinking as a critical element of top management when it comes to successful strategic processes. Hayes (1985) says managers must be able to think strategically to:

- understand the appropriate external environment;

- understand the capabilities and objectives of the organization;

- understand the connections between loosely connected events;

- recognize several influencers;

- sense new opportunities;

- see several strategies or solutions.

As Mintzberg (1994) stresses “strategic planning isn't strategic thinking. One is analysis, and the other is synthesis" (p. 107). Strategic thinking is recognized as a prerequisite for planning activities within an organization and is an important characteristic of managers. Strategic thinking is "the process of finding pattern or common thread related to the organization's activities which are derived from its policies, objectives and goals" (Dhir 
et al., 2018, p. 272). It is an ability that enables individuals to understand, visualize, and confront a given context. These authors identify four dimensions of strategic thinking: reflection, organizational awareness, trend analysis, and pattern recognition.

A study by Nuntamanop et al. (2013) found seven characteristics of strategic thinking that impact strategy formulation, strategic actions, and business performance: conceptual thinking ability, visionary thinking, analytical thinking ability, synthesizing ability, objectivity, creativity, and learning ability. According to Brønn (2014), a communication practitioner with strategic thinking competencies is likely to be proactive, issues-oriented, creative and innovative, organizationally well-informed, future-oriented, and a systems thinker. These are defined below:

- Organizationally aware - has extensive knowledge of important issues within the organization.

- Issues-oriented - has extensive knowledge of issues and changes in the external environment.

- Proactive - is proactive and encourages the introduction of new structures, methods, and guidelines.

- Creative and innovative - comes with very creative and innovative ideas.

- System thinkers - rises above the immediate problem or situation and sees the broader problem areas/issues and far-reaching consequences of them.

- Future-oriented - determines future priorities and can forecast foreseeable changes to meet future.

Creativity is required because of the need to be future-oriented, to make or create scenarios based on today's view of the world and possible futures. Analysis is required to make sensible and logical extrapolations and to present them in a readable and understandable manner.

Another model of strategic thinking competency is illustrated by Nuntamanop et al. (2013; Figure 1), who found evidence that strategic thinking competency impacts strategy formulation, which in turn influences 
strategic actions and subsequently business performance. In other words, strategic thinking competency contributes to the quality of the strategies and strategic directions.

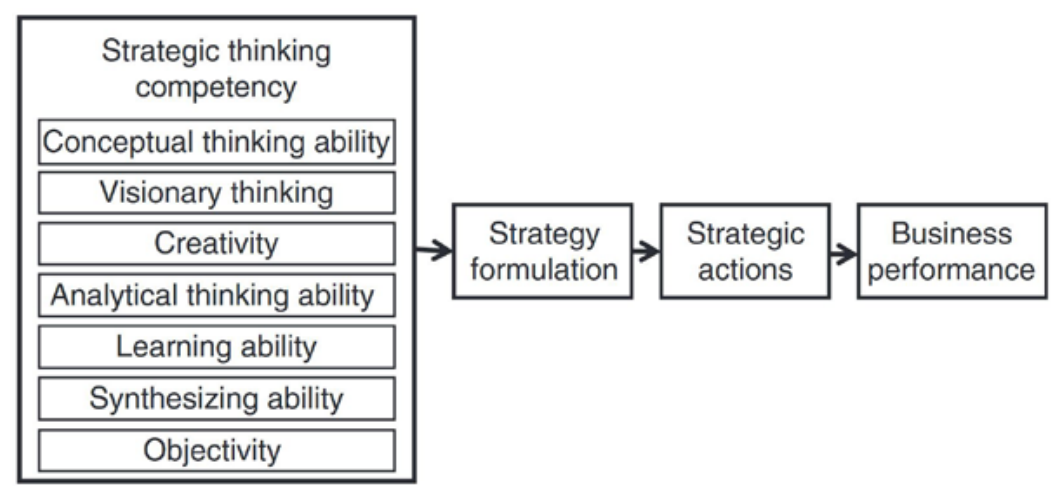

Figure 1 Model of strategic thinking competencies.

Source. From "A New Model of Strategic Thinking Competency", by P. Nuntamanop et al., 2013, Journal of Strategy and Management, 6(3), p. 256 (https://doi.org/10.1108/JSMA-102012-0052). Copyright 2013 by Emerald Group Publishing Limited.

The ability to think strategically is a primary requisite for being able to perform at the highest levels of an organization. The capability to create "sanity" out of an often unpredictable environment by making decisions that are complex and have a huge impact on the organization are key characteristics of managers who are part of the dominant coalition. And there is evidence that having a strategic orientation or being a strategic thinker is critical for communication's executive participation in decision-making. Brønn's (2014) research shows a correlation between strategic thinking and the personal influence of the communication executive, whether they have the support of top management, and the perception of the communication function on organizational success. More importantly, however, is the impact that strategic thinking has on communication executives' participation in top level meetings and the timing of participation in decision-making. They are significantly more likely to be invited to these meetings and at an early enough stage to make meaningful contributions. 


\section{Becoming a Strategic Thinker}

The set of abilities and skills discussed above are evidence of possessing "strategic thinking competency". Performing well on this competency is key to being involved in strategic decision-making with the top management team. However, the concept of "strategic thinking" is a difficult abstraction and while it is easy to report on what characteristics describe a strategic thinker, the question is if these can be learned, that is, is it possible to become a strategic thinker.

Most researchers agree that strategic thinking is built on the systems perspective, and that strategic thinking is also systems thinking (Haines, 2009; Liedtka, 1998). Systems thinking is concerned with developing and testing operational explanations of organizational behavior and requires an understanding of the whole through the relationships between organizational pieces. It also "focuses on relationships, multiple outcomes, holism and boundaries, the environment, the larger system and feedback" (Haines, 2009 , p. 1). As noted by Liedtka (1998), the systems thinker has a mental model "of the complete end-to-end system of value creation and understands the interdependencies with it" (p.122). The differences between traditional thinking and strategic or systems thinking are shown in Table 1.

Table 1 Comparing thinking traditions.

Source. Richmond, 1997.

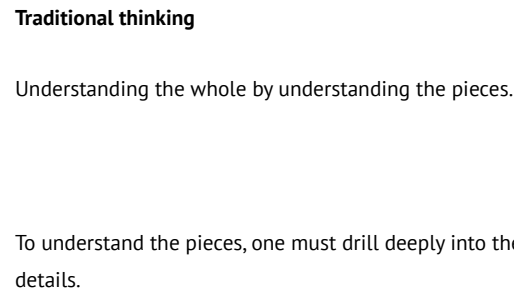

The pieces are unique; the boundaries are sharp; it is easy to categorize as "this, and not that".

Thus, to understand the pieces, precise measurement is required.

\section{Strategic/systems thinking}

To understand the whole, one must understand the relationships between the pieces.

The relationships generate performance over time.

To understand relationships or interconnections, it is necessary to have the knowledge and ability to understand relationships and interdependencies between system elements and push back from the detail of the individual pieces.

Pieces are unique, but relationships are generic; distinctions are not either/or but fall along a continuum. Quantification can aid in better understanding relationships, measurement comes later. 
Mental models are influenced by, for example, education, experiences, social roles and culture, and assumptions regarding the cause and effect relationships relevant for a problem.

Strategic thinking as a mental model arises from specific experiences (personal, interpersonal, organizational, and external), which occur gradually over time, normally 10 or more years (Goldman, 2007). Personal experience that influences strategic thinking include family upbringing and education, general work experience, and becoming a top leader. Interpersonal experience includes being mentored and being challenged by colleagues. Monitoring results and benchmarking, doing strategic planning, and spearheading a major growth initiative comprise organizational experiences. Finally, external experiences that impact strategic thinking are dealing with a threat to organizational survival and vicarious experiences.

In a qualitative study, Mellon and Kroth (2013) identified the experiences contributing to their subjects' development of the ability to think strategically. These were: being mentored, other people in their profession, education, practical experience, challenging experiences, experience in other cultures, and reading books. Table 2 lists the experiences and the characteristics associated with the experiences that contributed to the ability to become strategic thinkers.

Table 2 Important characteristics of experiences for learning strategic thinking.

Source. Mellon and Kroth, 2013, p. 73

$\begin{array}{ll}\text { Experiences contributing to strategic thinking } & \text { Important Characteristics } \\ \text { Being mentored } & \begin{array}{l}\text { Experienced strategic thinking } \\ \text { Affirming relationship } \\ \text { Facilitates reflective practice }\end{array} \\ \text { Other peers } & \text { New ideas } \\ & \text { Mutually supportive colleagues } \\ \text { Education } & \text { New ideas } \\ & \text { Challenging assumptions } \\ & \text { Learning to think critically } \\ \text { Practical experience } & \text { Variety } \\ & \text { Repetition } \\ & \text { Responsibility }\end{array}$




$\begin{array}{ll}\text { Challenging experiences } & \begin{array}{l}\text { Significant organizational impact } \\ \text { Responsibility } \\ \text { Required focus }\end{array} \\ \text { Experience in other cultures } & \begin{array}{l}\text { Challenging assumptions } \\ \text { Learning to listen }\end{array} \\ \text { Reading books } & \text { New ideas } \\ & \text { Challenging assumptions }\end{array}$

While strategic thinking is an individual competency, according to Goldman (2007) there are things that organizations can do to improve strategic thinking. Bonn (2001) refers to this as strategic thinking at the organizational level with the organization providing opportunities for individual strategic thinking. This includes creating structures, processes and systems that encourage strategic dialogue among top team members, and taking advantage of the "ingenuity and creativity of every individual employee" (Bonn, 2001, p. 66). Program suggestions by Goldman (2007) include:

- making strategic thinking a formal component of management development programs;

- requiring managers to develop strategic thinking of subordinates;

- encouraging early participation in strategic planning and benchmarking activities;

- supporting activities that incorporate experiential learning;

- maximizing the benefits of strategic planning sessions.

It is imperative that programs are highly individual as mental models are not the same in any two people. Further, programs must take place over at least a year and emphasis put on encouraging individuals to take responsibility for completing any initiatives.

Goldman (2007) does not address the communicative challenge of changing mental models, in this case moving from traditional thinking to systems thinking. This requires skills identified from the organizational learning literature (Argyris \& Schön, 1974): reflection, inquiry, and advocacy. These three organizational learning skills are central to the successful mastery of 
working with mental models. Reflection is an internally focused skill whose objective is to make the practitioner more aware of his or her own thinking and reasoning processes. Inquiry engages parties in a joint learning process where the objective is to understand the thinking and reasoning processes of the other party.

Advocacy is the process of communicating one's own thinking and reasoning in a manner that makes them visible for others. The reflective manager seeks to find a balance between inquiry and advocacy. Too much advocacy results in one-way communication with little feedback, too much inquiry means being bogged down. The objective of consciously developing these skills is to be able to surface the mental models and their underlying assumptions that are activated in a particular situation.

\section{Public Relations Tools and Strategic Thinking}

Thinking in terms of a formula of steps is the "essence of the strategic thinking Public Relations managers use", according to Heath and Coombs (2006, p. 137). Another characteristic that distinguishes a strategic thinker in public relations is "knowing that Public Relations tactics are not an end in and of themselves" (Heath \& Coombs, 2006, p. 167) but are for achieving objectives and accomplishing goals. This definition focuses on the planning aspect of work within public relations/strategic communication but as noted by Gulbrandsen and Just (2020), a plan does not determine the success of strategic communication, neither is strategic planning strategic thinking (Mintzberg, 1994).

Mapping techniques are an important aid for developing a systems perspective (Liedtka, 1998). Fortunately, students of public relations or strategic communication already have such tools. These are tools that reflect, and are recognized as being employed by, practitioners who are proactive or futures oriented. These tools deal with detecting and analyzing issues, selecting courses of action, and evaluating outcomes. They thus mirror the processes that represent a strategic way of thinking. They are all also systems models in that they imply iterative processes that occur continually within organizations as they seek to survive in rapidly changing environments.

One well-known tool is issues management (IM), developed in the 1970 s by W. Howard Chase, a veteran corporate public relations officer for American Can Company. IM is seen as a method for managing the numerous challenges and occurring changes facing organizations by identifying and analyzing 
issues, setting priorities, selecting strategy options, implementing a program of action and communication, and evaluating effectiveness.

Although communication was not explicitly identified, the IM model was designed to improve the effectiveness of organizational communication and to allow organizations to become proactive by identifying potential issues early enough for effective action. It adds value to organizations, according to Heath (2003) by strategically taking actions that can reduce costs and increase revenue. It is also a systems approach as it implies that change in one element of the system correspondingly affects other parts (Heath \& Nelson, 1985). The steps go on and on throughout all parts of the IM process system until the organization either succeeds or fails at its desired mission.

Issues monitoring requires environmental scanning, a radar-like vigilance used to spot potential or actual issues at their earliest point of development. As issues develop and mature, efforts are needed to identify and analyze them. Environmental scanning enables firms to identify both potential issues and stakeholders before they become problematic, or, conversely, to develop opportunities. Environmental scanning is an organizational methodology for collecting and analyzing information about every sector of the external environment that can help management. It is the activity that follows what is occurring within the environment that the organization operates. Environmental scanning is the acquisition and use of information about actors (stakeholders), events, trends, and relationships in an organization's external environment, the knowledge of which assists management in planning the organization's future course of action. It is generally agreed that this activity is a key component of strategic processes, as the acquisition of information is a major organizational effort.

Another tool is stakeholder mapping. Organizations exist in environments made up of stakeholders, those persons or groups of persons who are (a) impacted by the implementation of change initiatives, and/or (b) have a vested interest in the outcome of these initiatives (Freeman, 1984). It is imperative that communication departments are knowledgeable of an organization's stakeholders. Stakeholders may include donors to non-profit organizations, potential members, elected officials, church groups, judges and the legal community, business leaders, minority communities, trade associations, women's leaders, teens, senior citizens, and the general public. In addition to these important outside audiences, it is important for the organization not to forget its internal audiences, such as staff and board members. 
The ability to identify and analyze stakeholders (both internally and externally) is critical for an effective communication strategy. Managers can use a stakeholder analysis to identify the key actors and to assess their knowledge, interests, positions, alliances, and importance. This allows policymakers and managers to interact more effectively with key stakeholders and to increase support.

By combining influence and importance, stakeholders can be classified into different groups, which will help identify assumptions held by stakeholders. Influence refers to how powerful a stakeholder is; importance refers to those stakeholders who are the priority for the success of the communication efforts. Influence is perhaps best understood as the extent to which people, groups, or organizations (i.e., stakeholders) can persuade others into making decisions and following certain courses of action.

Exhibiting the use of these tools combined with an ability to think strategically can significantly increase a communication professional's standing within an organization. However, even though there are tools particularly relevant for strategic thinking, Zerfass, Volk, et al. (2018) found in a study of the use of management tools in corporate communications that there is room for improvement. The most used tools by communication professionals are editorial planning, topic planning, and media response analysis. Stakeholder maps were used in three out of four communications departments, but significantly fewer practitioners $(57.7 \%)$ are satisfied with their practical application.

\section{Ongoing Issues}

The comparative excellence framework for communication management (Tench et al., 2017) identified nine principles of excellence at the organizational, departmental, and professional level. At the departmental level, an excellent department is characterized as: embedded in decision-making processes, working closely with top management; datafied, using data for insights and automated communication; and strategized, which refers to the alignment of communication activities to overall goals. However, studies show that there is still a gap between how communication professionals view their contribution to organizations and how other leaders view their contribution, with communication professional rating their contribution significantly higher (Falkheimer et al., 2017; Zerfass \& Sherzada, 2015). 
Zerfass, Verčič, et al. (2018) found that even communication professionals themselves seem to have difficulties describing the core contributions of communication and in particular the strategic role of the department. Falkheimer et al. (2017) say this raises questions about the consequences of these views. For example, if the communication practitioners' function and contribution are not seen as important, their influence on strategic decision making may be reduced. Closing this gap then becomes tantamount and could be done by making the professionals' strategic thinking abilities clearer to other managers.

Perceived influence of communication executives was part of a 2019 study of corporate communication officers (CCOs) in Scandinavia's 150 most visible firms listed in the RepTrak reputation rankings (Brønn \& Brønn, 2019). To learn more about the communication executives' position in their organizations, a simple exercise was carried out to map their visibility and presentation on the companies' websites; whether they were listed with the top management team, on the firm's site for press contacts/media relations, or both.

Results showed that many communication executives are not recognized as legitimate members of the top management team, but instead are only listed on a press contacts site. Sweden is clearly the leader in recognizing their CCOs as part of their top management team on firm websites, with $67 \%$ of CCOs listed with the chief executive officer and other top leaders and $33 \%$ only under press contacts. Norway follows with $54 \%$ listed with the top management team and $46 \%$ only under press contacts/media relations. The results for Denmark are distinctly different. A mere $13 \%$ of the CCOs in Denmark's most visible firms are listed with their top management team, meaning that a high $87 \%$ of Danish communication executives are only listed under media relations/press contacts.

It is possible to argue that inclusion with senior leaders on the website sends a signal that the head of communication is equal to other top executives. This is important as where CCOs sit within an organization says something about the organization's perception of the importance of not only the CCO's role, but also of communication itself. The findings presented here represent only three countries, one of which performed very poorly. Clearly, there is more work to be done. 


\section{Conclusion}

In a 2012 interview with Public Relations Society of America, Robert Scott Pritchard, instructor and faculty adviser at the University of Oklahoma, was asked what is most important for students to learn and what tools do they need to be fluent in, in order to succeed. He answered that:

it was less about the tools and more about their strategic thinking. Being able to see the big picture can be learned if students are willing to put in the effort to do so and if we coach them correctly. Developing a leadership mentality is also of prime importance. One of the myths of leadership is that you have to have the title to be a leader. (Jacques, 2012)

For public relations executives, the three most important qualities of excellent leadership are: strategic decision-making capability, problem-solving ability, and communication knowledge and expertise (Meng et al., 2012). These competencies clearly match those demonstrated by strategic thinkers. However, subsequent research from Meng (2013) shows that students of public relations find the top three unique leadership qualities are: having the ability to cultivate relationships with key publics, having a comprehensive understanding of the needs and concerns of diverse publics, and having a compelling vision of communication for the organization. This is a considerable gap in perceptions, but as noted by Meng, the gap provides insight into how curriculum changes can be made that might better prepare public relations students for leadership positions.

Leadership tools and education are both available, as are strategic thinking tools and education. Key for practitioners is learning and enacting them. Otherwise, strategic communication becomes just another buzz word and never fulfills its promise of contributing to the survival and sustained success of an entity because communication professionals will continue to be viewed as message producers and technicians.

\section{References}

Argenti, P. A., Howell, R. A., \& Beck, K. A. (2015). The strategic communication imperative. MIT Sloan Management Review, 61-67. http://marketing.mitsmr.com/PDF/STR0715-Top-10-Strategy.pdf\#page $=63$

Argyris, C., \& Schön, D. (1974). Theory in practice: Increasing professional effectiveness. Jossey-Bass Publishers. 
Bonn, I. (2001). Developing strategic thinking as a core competency. Management Decision, 39(1), 63-70. https://doi.org/10.1108/EUM0000000005408

Botan, C. H. (2018). Strategic communication theory and practice: The cocreational model. John Wiley \& Sons.

Broom, G. M., \& Dozier, D. M. (1986). Advancement for public relations role models. Public Relations review, 12(1), 37-56. https://doi.org/10.1016/S0363-8111(86)80039-X

Brønn, P. S. (2001). Communication managers as strategists? Can they make the grade? Journal of Communication Management, 5(4), 313-326. https://doi.org/10.1108/13632540110806857

Brønn, P. S. (2014). How others see us: Leaders' perceptions of communication and communication managers. Journal of Communication Management, 18(1), 58-79. https://doi.org/10.1108/ JCOM-03-2013-0028

Brønn, P. S., \& Brønn, C. (2019, July 4-6). Changing how reputation is studied: From outcomes to process [Paper presentation]. 26th International Public Relations Symposium, BledCom 2019, Lake Bled, Slovenia.

Cardwell, L. A., Williams, S., \& Pyle, A. (2017). Corporate public relations dynamics: Internal vs. external stakeholders and the role of the practitioner. Public Relations Review, 43(1), 152-162. https://doi.org/10.1016/j.pubrev.2016.11.004

Chakravarthy, B. S., \& Lorange, P. (1991). Managing the strategy process: A framework for a multibusiness firm. Prentice Hall.

Dhir, S., Dhir, S., \& Samanta, P. (2018). Defining and developing a scale to measure strategic thinking. Foresight, 20(3), 271-288. https://doi.org/10.1108/FS-10-2017-0059

Dozier, D. M. (1992). The organizational roles of communications and public relations practitioners. In J. E. Grunig (Ed.), Excellence in public relations and communication management (pp. 327-355). Lawrence Erlbaum.

Falkheimer, J., Heide, M., Nothhaft, H., von Platen, S., Simonsson, C., \& Andersson, R. (2017). Is strategic communication too important to be left to communication professionals? Managers' and coworkers' attitudes towards strategic communication and communication professionals. Public Relations Review, 43(1), 91-101. https://doi.org/10.1016/j.pubrev.2016.10.011

Frandsen, F., \& Johansen, W. (2017). Strategic communication. In C. Scott \& L. Lewis (Eds.), The international encyclopedia of organizational communication (Vol. 4, pp. 1-9). International Communication Association (ICA); Wiley-Blackwell. https://doi.org/10.1002/9781118955567. wbieoc194

Freeman, R. E. (1984). Strategic management: A stakeholder approach. Pitman.

Goldman, E. F. (2007). Strategic thinking at the top. MIT Sloan Management Review, 48(4), 75-82. https://sloanreview.mit.edu/wp-content/uploads/saleable-pdfs/48418.pdf 
Grunig, J. (2006). Furnishing the edifice: Ongoing research on public relations as a strategic management function. Journal of Public Relations Research, 18(2), 151-176. https://doi. org/10.1207/s1532754xjprr1802_5

Grunig, L. A. (1992). How public relations/communication departments should adapt to the structure and environment of an organization... And what they actually do. In J. E. Grunig (Ed.), Excellence in public relations and communication management (pp.467-481). Lawrence Erlbaum.

Gulbrandsen, I.T., \& Just, S. N. (2020). Strategizing communication: Theory and practice. Sanfunds Litterature.

Haines, S. (2009). Becoming a strategic thinker on a daily basis: Raise your strategic IQ for 21st century success. Haines Center for Strategic Management. http://adaptknowledge.com/wp-content/uploads/Docs/abst_sst_2.pdf

Hayes, M. (1985). Developing managers for strategic management, In W. D. Guth (Ed.), Handbook of business strategy (pp. 420-444). Warren, Gorham \& Lamont Publishing.

Hallahan, K., Holtzhausen, D., Van Ruler, B., Verčič, D., \& Sriramesh, K. (2007). Defining strategic communication. International journal of strategic communication, 1(1), 3-35. https://doi. org/10.1080/15531180701285244

Heath, R. L. (2003). The importance of issues management and environmental scanning for corporate image. In P. S. Brønn \& R. Wiig-Berg (Eds.), Corporate communication: A strategic approach to building reputation (pp.147-165). Gyldendal.

Heath, R. L., \& Coombs, T. W. (2006). Today's public relations: An introduction. Sage Publications.

Heath, R. L., \& Nelson, R. A. (1985). Issues management. Sage Publications.

Hinterhuber, H. H., \& Popp, W. (1993). What makes a strategist out of a manager? What engineers should know about strategic management. International Journal of Production economics, 30, 297-307. https://doi.org/10.1016/0925-5273(93)90100-Y

Jacques, A. (2012, October 3). The PR classroom of the future: 5 educators share advice on teaching the millennial generation. PRSA. https://apps.prsa.org/Intelligence/Tactics/Articles/ view/9934/1055/The_PR_classroom_of_the_future_5_educators_share_a\#.YP7qYegzZyE

Katzenbach, J. R. (1996). New roads to job opportunity: From middle manager to real change leader. Strategy \& Leadership, 24(4), 32-36. https://doi.org/10.1108/eb054562

Liedtka, J. M. (1998). Strategic thinking: Can it be taught? Long Range Planning, 31(1), 120-129. https://doi.org/10.1016/S0024-6301(97)00098-8

Mellon, J., \& Kroth, M. (2013). Experiences that enable one to become an expert strategic thinker. Journal of Adult Education, 42(2), 70-79. https://eric.ed.gov/?id=EJ1047342

Meng, J. (2013). Learning by leading: Integrating leadership in public relations education for an enhanced value. Public Relations Review, 39(5), 609-611. https://doi.org/10.1016/j.pubrev.2013.09.005 
Meng, J., Berger, B. K., Gower, K. K., \& Heyman, W. C. (2012). A test of excellent leadership in public relations: Key qualities, valuable sources, and distinctive leadership perceptions. Journal of Public Relations Research, 24(1), 18-36. https://doi.org/10.1080/1062726X.2012.626132

Mintzberg, H. (1989). Mintzberg on management: Inside our strange world of organizations. Simon and Schuster.

Mintzberg, H., 1994. The rise and fall of strategic management. Harvard Business Review, 1(02).

Nuntamanop, P., Kauranen, I., \& Igel, B. (2013). A new model of strategic thinking competency. Journal of Strategy and Management, 6(3), 242-264. https://doi.org/10.1108/JSMA-10-20120052

Richmond, B. (1997). The "thinking" in systems thinking: how can we make it easier to master? The Systems Thinker, 8(2), 1-5.

Schilit, W. K. (1993). A comparative analysis of strategic decisions. Journal of Management Studies, 27(5), 435-461. https://doi.org/10.1111/j.1467-6486.1990.tb00256.x

Tench, R., Verčič, D., Zerfass, A., Moreno, Á., \& Verhoeven, P. (2017). Communication excellence: How to develop, manage and lead exceptional communications. Palgrave Macmillan.

Vaghefi, R., \& Huellmantel, A. B. (1998). Strategic management for the XXIst century. CRC Press.

White, J. \& Dozier, D. M. (1992). Public relations and management decision making. In J. E. Grunig (Ed.), Excellence in public relations and communication management (pp. 91-108). Lawrence Erlbaum.

Wilson, C. (2016). How dominant coalition members' values and perceptions impact their perceptions of public relations participation in organizational decision making. Journal of Communication Management, 20(30), 215-231. https://doi.org/10.1108/JCOM-07-2015-0058

Zabriskie, N. B., \& Huellmantel, A. B. (1991). Developing strategic thinking in senior management. Long Range Planning, 24(6), 25-32. https://doi.org/10.1016/0024-6301(91)90040-U

Zerfass, A., \& Sherzada, M. (2015). Corporate communications from the CEO's perspective: How top executives conceptualize and value strategic communication. Corporate Communications: An International Journal, 20(3), 291-309. https://doi.org/10.1108/CCIJ-04-2014-0020

Zerfass, A., Verčič, D., Nothhaft, H., \& Werder, K. P. (2018). Strategic communication: Defining the field and its contribution to research and practice. International Journal of Strategic Communication, 12(4), 487-505. https://doi.org/10.1080/1553118X.2018.1493485

Zerfass, A., Volk, S. C., Lautenbach, C., \& Jakubowitz, M. (2018, October 7). Management tools for corporate communications: Relevance, benefits and experiences. Results of an empirical study in communication departments [PowerPoint slides]. SlideShare. https://www.slideshare.net/communicationmanagement/management-tools-for-corporate-communications-relevance-benefits-and-experiences-results-of-an-empirical-study-in-communication-departments-118542582 